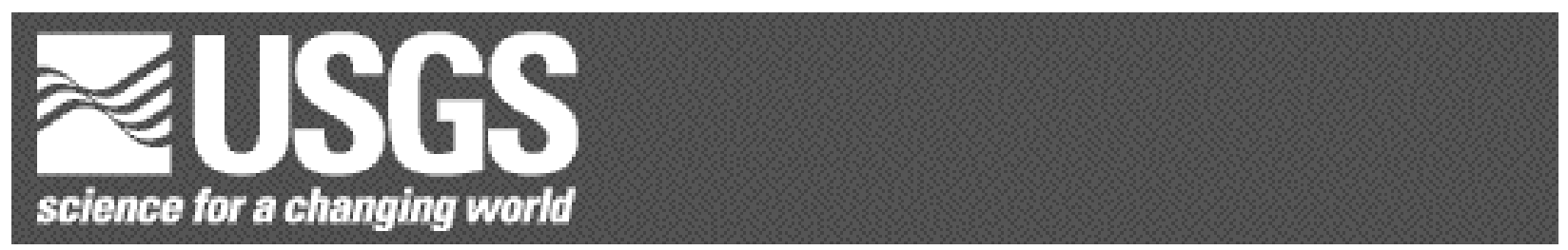

\title{
Chemical Analyses Of Tertiary Volcanic Rocks, Central San Juan Caldera Complex, Southwestern Colorado
}

By Peter W. Lipman 1

Open-File Report 2004-1194

2004

Any use of trade, firm, or product names is for descriptive purposes only and does not imply endorsement by the U.S. Government.

U.S. DEPARTMENT OF THE INTERIOR

U.S. GEOLOGICAL SURVEY

${ }^{1}$ Menlo Park, Calif. 
In conjunction with integrated mapping of the central San Juan caldera cluster (Lipman, in press), all modern chemical analyses of volcanic rocks for this area determined in USGS laboratories have been re-evaluated in terms of the stratigraphic sequence as presently understood (Lipman, 2000). These include approximately 700 analyses made in laboratories of the U.S. Geological Survey between 1986 and 2003, as well as all USGS analyses published since 1965 when the widespread presence of regional welded ash-flow tuffs erupted from large calderas was first recognized (Steven and Ratté, 1965; Ratté and Steven, 1967). The table also includes recent USGS analyses made for samples from the Cochetopa Park region, where geologic mapping is in progress (2004) just northeast of the central San Juan map area. A few published analyses for major units erupted from the central San Juans, but from beyond the present map, are also tabulated. All the analyses are assigned unit identifiers consistent with those used for the new geologic map; quite a few of these differ from those used on sample submittal forms and prior USGS publications.

In addition to the USGS analyses, selected analyses determined at other institutions have been tabulated for major map units where helpful to provide more complete representation. These include the Blue Creek and Wason Park Tuffs (Webber, 1988), Carpenter Ridge Tuff (Whitney and others, 1988; Dorais and others, 1991), Fish Canyon Tuff and Pagosa Peak Dacite (O'Leary, 1981; Whitney and Stormer, 1985; Bachmann, 1997; Bachmann and others, 2002), and Huerto Andesite (Askren and others, 1991; Parat, 2001). Unit assignments for all published analyses have been evaluated and revised where appropriate.

Analyses compiled include major oxides determined by wave-length dispersive $x$-ray fluorescence (WDXRF) and some older analyses by wet-chemical methods, and trace elements determined by energy-dispersive $x$-ray fluorescence (Kevex), instrumental neutron activation (INAA), and induction-coupled plasma spectroscopy (ICP). Analytical methods for recent USGS analyses are described by Taggart and others (1987) for XRF major oxides, by Siems (2000) for XRF trace elements, Budahn and Wandless (2002) for INAA determinations, and by Lichte and others (1987) for ICP analyses. Special thanks are owed to Dave Siems for producing, with rapid turnaround times, so many XRF determinations for this effort during the past 10 years. For published analyses, see the cited sources for analytical methods. Analyses of major 
oxides are recalculated to the reported totals, volatile free. Analyses of glassy rocks (vitrophyres) are typically high in $\mathrm{K}_{2} \mathrm{O}$ and low in $\mathrm{Na}_{2} \mathrm{O}$, due to alkali exchange (Lipman, 1964). Some devitrified samples from the Creede mining district are very high in $\mathrm{K}_{2} \mathrm{O}$ and correspondingly low in $\mathrm{Na}_{2} \mathrm{O}$, reflecting strong $\mathrm{K}$-metasomatism (Ratté and Steven, 1967; Sweetkind and others, 1993). For trace-element determinations, detectability limits, precision, and elements reported have varied significantly during the past 30 years during which analyses have been made, and the table displays some inconsistencies in significant figures reported and in elements analyzed as a result. A few older analyses are unreliable for some trace elements (e.g., $\mathrm{Sr}$ and $\mathrm{Rb}$ from Whitney and Stormer, 1985). A few particularly suspect analytical values are italicized.

Sample sites for the analyses were located geographically as reliably as possible, listed by longitude and latitude on the table, and will be plotted on the same base as the new geologic map (Lipman, in press). Wherever possible, locations have been plotted directly from 1:24,000 -scale 7.5' field sheets. For some previously published analyses, precise locations could not be recovered, either for lack of adequate published descriptions, or because listed latitude and longitude coordinates were inconsistent with the designated volcanic unit or the rock composition. Some locations for these analyses are only approximate, and locations of others are not known adequately to list in the table or plot on the base map. 


\section{Sources of previous published chemical data:}

$\begin{array}{llr}\text { Reference } & \text { Unit or area covered } & \text { No. of analyses } \\ \text { Askren, 1992 } & \text { Sheep Mtn, Bristol Head Andesites } & 12 \\ \text { Askren and others, 1991 } & \text { Huerto Andesite } & 27 \\ \text { Askren and others, 1997 } & \text { Andesitic lava flows } & 4 \\ \text { Bachmann, 1997 } & \text { Pagosa Pk Dacite, Fish Canyon Tuff } & 48 \\ \text { Bachmann and others, 2002 } & \text { Pagosa Pk Dacite, Fish Canyon Tuff } & 9 \\ \text { Dorais and others, 1991 } & \text { Fiamme, Carpenter Ridge Tuff } & 11 \\ \text { Fleurat, 2001 } & \text { Huerto Andesite } & 36 \\ \text { Lipman, 1975 } & \text { Platoro caldera complex } & 21 \\ \text { Lipman, 1987 } & \text { INAA analyses } & 15 \\ \text { Lipman and others, 1996 } & \text { Masonic Park, Chiquita Pk Tuffs } & 20 \\ \text { O'Leary, 1981 } & \text { Fish Canyon Tuff } & 22 \\ \text { Olson and others, 1968 } & \text { Northern San Juan slope } & 2 \\ \text { Ratté and Steven, 1967 } & \text { Creede mining district } & 36 \\ \text { Riciputi, 1991 } & \text { Central San Juan region } & 122 \\ \text { Webber, 1988 } & \text { Central San Juan tuffs } & \\ \text { Whitney and Stormer, 1985 } & \text { Fish Canyon Tuff } & 22 \\ \text { Whitney and others, 1988 } & \text { Carpenter Ridge Tuff } & 22 \\ \text { Yager and others, 1991 } & \text { Lava flows, S-central San Juans } & 83\end{array}$

\section{References:}

Askren, D.R., 1992, Origin of andesites interlayered with large-volume ash-flow tuffs in the western United States: PhD dissertation, University of Georgia, 281 pp.

Askren, D.R., Whitney, J.A., and Roden, M.F., 1991, Petrology and geochemistry of the Huerto Andesite, San Juan volcanic field, Colorado: Contributions to Mineralogy and Petrology, v. 107, p. 373-386.

Askren, D.R., Roden, M.F., and Whitney, J.A., 1997, Petrogenesis of Tertiary andesite lava flows interlayered with large-volume felic ash-flow tuffs of the Western USA: Jour. Petrology, v. 38, p. 1021-1046 
Bachmann, O., 1997, The Alboroto Group, San Juan volcanic field, Colorado: Insights into large caldera cycles: Diplome, Universite de Geneve, (Switzerland)

Bachmann, O, Dungan, M.A., and Lipman, P.W., 2002, The Fish Canyon magma body, San Juan volcanic field, Colorado: rejuvenation and eruption of an upper crustal batholithic magma chamber: Journal of Petrology, v. 43, p.1469-1503.

Budahn, J. R., and Wandless, G. A., 2002, Instrumental neutron activation by long count: U. S. Geological Survey Open-File Report 2002-0223, pp.X1-X13.

Dorais, M.J., Whitney, J.A., and Stormer, J.C. Jr, 1991, Mineralogical constraints on the petrogenesis of trachytic inclusions, Carpenter Ridge Tuff, central San Juan volcanic field, Colorado: Contributions to Mineralogy and Petrology, v. 107, p. 219-230.

Parat, F., 2001, Contemporaneous magmatic differentiation of S-rich trachyandesitic and high-K calc-alkaline andesite in an intracontinental setting, San Juan volcanic field, Colorado, U.S.A.: University of Geneva, Switzerland, Ph.D dissertation, 121 p.

Lichte, F.E., Golightly, D.W., and Lamothe, P.J., 1987, Inductively coupled plasmaatomic emission spectrometry, in Baedecker, Philip A., ed., Methods for geochemical analysis: U. S. Geological Survey Bulletin 1770, p. B1-B10.

Lipman, P.W., 1964, Chemical comparison of glassy and crystalline volcanic rocks: U.S. Geological Survey Bulletin 1201-D, 24 p.

Lipman, P.W., 1975, Evolution of the Platoro caldera complex and related volcanic rocks, southeastern San Juan Mountains, Colorado: U.S. Geological Survey Professional Paper 852, 128 p.

Lipman, P.W., 1987, Rare-earth-element compositions of Cenozoic volcanic rocks in the southern Rocky Mountains and adjacent areas: U.S. Geological Survey Bulletin $1668,23 \mathrm{p}$.

Lipman, P.W., 2000, The central San Juan caldera cluster: Regional geologic framework, in Bethke, P.M., and Hay, R.L., eds., Ancient Lake Creede: its volcano-tectonic setting, history of sedimentation, and relation to mineralization in the Creede mining district: Geological Society of America Special Paper 346, p. 9-70. 
Lipman, P.W., in press, Geologic map of the Central San Juan caldera cluster, southwestern Colorado: U.S. Geological Survey Misc. Investigations Map I-2799, 1:50,000, 3 sheets.

Lipman, P.W., Dungan, M.A., Brown, L.D., and Deino, A., 1996, Recurrent eruption and subsidence at the Platoro caldera complex, southeastern San Juan volcanic field, Colorado: New tales from old tuffs: Geological Society of America Bulletin, v. 108, p. 1039-1055.

O'Leary, W.J., 1981, The magmatic paragenesis of the Fish Canyon ash-flow tuff, central San Juan Mountains, Colorado: MS Thesis, University of Georgia, 103 p. Olson, J.C., Hedlund, D.C., and Hansen, W.R., 1968, Tertiary volcanic stratigraphy of the Powderhorn-Black Canyon region, Gunnison and Montrose Counties, Colorado: U.S. Geological Survey Bulletin 1251-C, 29 pp.

Ratté, J.C., and Steven, T.A., 1967, Ash flows and related volcanic rocks associated with the Creede caldera, San Juan Mountains, Colorado: U.S. Geological Survey Professional Paper 524-H, 58 p.

Riciputi, L.R., 1991, Petrology and Nd, Sr and Pb isotopes of the central San Juan caldera cluster, Colorado: PhD. thesis, University of Wisconsin-Madison.

Siems, D.F., 2000, The determination of 30 elements in geological materials by energydispersive X-ray fluorescence spectrometry: US. Geological Survey Open-File Report OF 00-475, 13 pp.

Steven, T.A., and Ratté, J.C., 1965, Geology and structural control of ore deposition in the Creede district, San Juan Mountains, Colorado: U.S. Geological Survey Professional Paper 487, 90 p.

Sweetkind, D.S., Reynolds, R.L., Sawyer, D.A., and Rosenbaum, J.G., 1993, Effects of hydrothermal alteration on the magnetization of the Oligocene Carpenter Ridge Tuff, Bachelor caldera, San Juan Mountains, Colorado: Journal of Geophysical Research, v. 98, p. 6255-6266.

Taggart, Joseph E., Jr., Lindsey, J.R., Scott, B.A., Vivit, D.V., Bartel, A.J., and Stewart, K.C., 1987, Analysis of geologic materials by wavelength-dispersive X-ray fluorescence spectrometry, in Baedecker, P.A., Methods for geochemical analyses: U.S. Geological Survey Professional Paper 1770, P. E1-E19. 
Webber, K.L., 1988, The Mammoth Mountain and Wason Park Tuffs: magmatic evolution in the central San Juan volcanic field, southwestern Colorado: PhD. thesis, Rice University, Houston, Texas, $244 \mathrm{p}$.

Whitney, J.A., and Stormer, J.C. Jr., 1985, Mineralogy, petrology, and magmatic conditions from the Fish Canyon Tuff, central San Juan volcanic field, Colorado: Journal of Petrology, v. 26, p. 726-762.

Whitney, J.A., Dorais, M.J., Stormer, John C. Jr., Kline, S.W., and Matty, D.J., 1988, Magmatic conditions and development of chemical zonation in the Carpenter Ridge Tuff, central San Juan volcanic field, Colorado: American Journal of Science, v. 288-A, p. 16-44.

Yager, D.B., Lipman, P.W., and Sawyer, D.A., 1991, Caldera-related lava flows and intrusions of the south-central San Juan Mountains, Colorado--Analytical data: U.S. Geological Survey Open-File Report 91-313, 19 p. 